\title{
Review of James E. Alvey's A short history of ethics and economics: the Greeks. Cheltenham (UK): Edward Elgar, 2011, 184pp.
}

\author{
SPENCER J. PACK \\ Connecticut College
}

This rather brief work on the relationship between classical ancient Greek thought and economics is apparently the first part of a much larger grand history of the relationship between ethics and economics (p. vii). The book basically follows the template of S. Todd Lowry's magisterial The archaeology of economic ideas: the classical Greek tradition (1987). Indeed, it is sort of an abridged version of Lowry's work, though much thinner-more like a sketch or an outline.

As with Lowry, there are sections dealing with the Sophists, Xenophon, Plato, and Aristotle. For the most part Alvey agrees with Lowry's interpretations. There are just a few differences. One is that Alvey stresses more the differences between the latter Plato, as found in the Laws and the Statesman, and Plato's early and middle dialogues, particularly the well known Republic. Alvey explains how the Republic is a utopian ideal of a perfectly virtuous city, with rule by philosophers; the abolition of private property for the warrior class; and gender equality, so some women will be philosophers and hence rulers. These are radical, revolutionary proposals on education and gender. Alvey paints Plato here as an early capability theorist in a long tradition which today manifests itself in the work of Amartya Sen and Martha Nussbaum. On the other hand, Plato's Laws and the Statesman are more practical: they detail what might be achieved in a real city, although the city's goal is still nobility. The later Plato realizes that, since the rule of an outstanding individual looking out for the benefit of others is rare and such people are not easily identified, there is a need for the rule of law. Hence, the rule of law is the best possible regime, replacing the utopian standard of rule by philosophers in the Republic. The Laws provides a model for law-givers, in which it is the written law and various important customs which shape the behavior and character of those who are compelled to obey them. 
In another divergence from Lowry, Alvey distinguishes two major traditions relating ethics and economics, both stemming from Aristotle. One currently manifests itself in the Straussian school, with the work of Leo Strauss, and his followers Joseph Cropsey, Richard Stavely, and, more recently, such theorists as Peter Minowitz, Richard Temple-Smith, and Athol Fitzgibbons. The Straussians are basically elitists, stressing the aristocratic side of Aristotle, and the fundamental inequality of humans in terms of their potential for and achievements in developing the intellectual and moral virtues. The other tradition manifests itself in the work of Sen and Nussbaum. In their more egalitarian capabilities approach, Sen and Nussbaum stress that everyone has an entitlement or right to certain basic functionings or capabilities required for human flourishing. Hence, Sen and Nussbaum stress a more democratic side or interpretation of Aristotle. Nonetheless, both of these grand narratives have commonalities. For Alvey, both show the existence of a once vibrant ethical tradition in the history of economic thought; they agree that the ethical tradition in economics has largely faded out, and consider the current state of economics to be either ethically thin or amoral; and hence they both largely endorse the past over the present.

Alvey himself is a bit torn between these two grand narratives. Alvey was a student of the Straussian Stavely, and adopted his interpretation for a decade or so, before abandoning most of the doctrine (p. 8). Alvey is now more sympathetic to the Sen-Nussbaum approach. Nonetheless, Alvey concludes that "Nussbaum's social democratic interpretation of Aristotle is a distortion" (p. 154). Although in a footnote Alvey does accept that the approach of Sen and Nussbaum "is not a mere history of ideas" but contemporary political theory which is "Aristotelian in spirit", and that Aristotle is used by Sen and Nussbaum as a "tool for contemporary critique and progressive social reform" (p. 156, 8fn.).

I think the key difference between these two interpretations of Aristotle is who should be a citizen of the state; or, how broadly should citizenship be defined. For Aristotle the best regime allows for every citizen to live a flourishing life. Aristotle himself tended to take a narrow view of who should be a citizen. Yet if one takes a broad based conception of who should count as a citizen, then the Sen-Nussbaum capabilities approach is definitely Aristotelian. As Jill Frank persuasively argues in her A democracy of distinction: Aristotle and the work of politics (2005), Aristotle's activity-oriented philosophy does harbor democratic possibilities. She writes: 
some commentators conclude, on the basis of Aristotle's account of practical wisdom and virtue, that the political order he endorses must be exclusionary and antidemocratic. There is plenty of evidence in Aristotle's writings to support this conclusion: he excludes from citizenship women and slaves on the basis of their inferior practical wisdom. He excludes artisans and laborers on the ground that what they do interferes with the cultivation of the virtues necessary for citizenship. There is, however, nothing intrinsic to Aristotle's understanding of practical wisdom to support these exclusions (Frank 2005, 122).

Moreover, as with Hegel, the great systematizer of the 19th century, we might also expect that Aristotle, the great systematizer of the ancient world, would have his system split apart into what may be called left and right wing, or egalitarian and aristocratic, interpretations (Pack 2010). Readers interested in a brief account of the relation between classical Greek thought and economics will find Alvey's book worthwhile. However, they would probably be better served by dipping into Lowry's work; or, better yet, studying Lowry's (1987) entire book including his extensive endnotes. Meanwhile, we can look forward to Alvey's larger grand history of the relationship between ethics and economics; the material in the current book will no doubt have an important place at or near the beginning of that ambitious story.

\section{REFERENCES}

Frank, Jill. 2005. A democracy of distinction: Aristotle and the work of politics. Chicago: University of Chicago Press.

Lowry, S. Todd. 1987. The archaeology of economic ideas: the classical Greek tradition. Durham: Duke University Press.

Pack, Spencer J. 2010. Aristotle, Adam Smith, and Karl Marx: on some fundamental issues in 21st century political economy. Cheltenham (UK): Edward Elgar.

Spencer J. Pack is professor of economics at Connecticut College, New London, Connecticut, USA. His recent publications include Aristotle, Adam Smith, and Karl Marx: on some fundamental issues in 21st century political economy (Edward Elgar, 2010) and "Aristotle's difficult relationship with modern economic theory" (Foundations of Science, 13 (3-4), 2008).

Contact e-mail: <sjpac@conncoll.edu> 